Sport injuries among the junior women duelists according to the type of weapon

*Lect.Dr/ Mohamed Mahmoud Mohamed Soliman

**Lect.Dr/ Mohamed Khamis Anwar Ibrahim

\title{
Introduction
}

Fencing is characterized by the attack, defense, deception and quick blade movements which is performed by duelist and accompanied by the movements of the body and weapon at the same time what exposes the duelist to the different sport injuries, which represent psychological and physical barrier where becomes an obstruction in the way to high levels which considered as a one of the duelist exclusion factors from sport competitions, in addition to decreasing the sport accomplishing rates, which leads to duelist loss.(15)

*Lecturer at the department of combats and individual sports training - faculty of physical education (men) Alexandria University - Arab republic of Egypt

**Lecturer at the department of biological science and sport health faculty of physical education (men) Alexandria University - Arab republic of Egypt

Fencing contains several skills that require different technical aspects, and injuries issue is considered as a one of the significant problems that need more study, as the injury danger significantly varys in terms of quantity and quality. Specialists in this field aim to ensure the provision of security and safety as much as possible for individuals and protect them from injury and its danger, and this 
requires creating rules for the security and safety of participants in fencing. (10:189)

Sport injuries vary according to the type of practiced physical activity as the injuries of individual games differ from the mass ones depending on the degree of direct contact with the opponent, as the case in the sport of boxing, fencing, athletics events, or swimming.

As well as the places of injuries vary from one sport to another, according to the used part in the body in sports activity where the proportion of injuries increases in the lower limb in some games such as football, while the percentage increase in the high limb in some other games. (11:16)

Osama Abdul Rahman (1999) refers that the nature of performance in fencing is characterized by instability according to the reactions between duelists, where the movements vary according to the positions of play and its change, and there is no previous preparation or pre-programmed performance that fencing is characterized by performing the open-skills indeterminate sentences. (13:9)

Nick (1996), Hussein Haggag and Ramzy Altunboly (2005) mentioned that fencing requires duelist to make a great effort at a specific time with the possibility of duelist's continuing in performance for long periods and possession of physical, psychological and skill capabilities, especially in terms of offensive \& defensive skills, and basic movements of the legs.(8:7) (12:132)

Despite the importance of the safety of the players in the sport of fencing, but there were not many studies that suggest for the prevention of injuries although amend laws and the used tools to play to preserve them, for example in the World Championship in 1951 one of the players suffered to fatal penetrate injury so has been recommending to use the chest protector (plastron) that be worn under the jacket for increasing the player protection. As a result of this recommendation led to a decline in the rate of injuries. (2:17) $(6: 265)(14: 465)$ 
this study shows the importance of the work of the analytical study of the infinite nature and causes of injuries that faced by female duelists, and the most vulnerable places to injury in fencing, which through contribute in the prevention of the sports injuries breakout, and working on the players to reach high levels

\section{Study aims}

Identification of the sports injuries among junior women duels according to the type of weapon.

\section{The study questions}

Identification of sports injuries to the fencing juniors according to the type of used weapon and through the following questions:

- Is there any type of injuries expose duels during the practice of fencing?

- Is there a relationship between the type of injury and the type of used weapon at the junior women duels?

- Is there a relationship between the injured parts and type of used weapon?

- Is there a relationship between the timing of the incidence and type of used weapon during the training season?

- Is there a relationship between the type of used weapon and the cause of your exposure to injury?

\section{Methodology}

Researchers used the descriptive method by making survey for its suitability of the nature of research.

\section{The human sphere}


The research sample included 53 of the junior women duelists that aged between 14-17 years and some of the conditions have been put to adjust the sample:

- All sample members under 17 years old.

- Fencing practicing years not less than 3 years.

- must be registered at the Egyptian Fencing Federation.

-participated in at least one of the Egyptian Federation of Fencing Championships.

\section{Spatial field}

All research measurements were applied in (the Alexandrian weapon - Sporting and Egyptian weapon) clubs.

\section{Temporal field}

Research was applied during the period from 14/6/2014 until 2/10/2014

Table (1) statistical characterization of the data sample in the basic variables $n=53$

\begin{tabular}{|l|l|l|l|l|l|}
\hline \multirow{2}{*}{} & \multicolumn{5}{|l|}{ Statistical indications of characterization } \\
\cline { 2 - 7 } & $\begin{array}{l}\text { Arithmetic } \\
\text { mean }\end{array}$ & median & $\begin{array}{l}\text { Standard } \\
\text { deviation }\end{array}$ & $\begin{array}{l}\text { Splaying } \\
\text { coefficien } \\
\text { t }\end{array}$ & $\begin{array}{l}\text { Torsion } \\
\text { coefficien } \\
\text { t }\end{array}$ \\
\hline Age & 14.55 & 15 & 1.80 & 0.12 & -0.49 \\
\hline Length & 162.09 & 161 & 6.74 & 0.27 & 0.07 \\
\hline $\begin{array}{l}\text { Training } \\
\text { old }\end{array}$ & 3.58 & 3 & 2.36 & 1.76 & 0.96 \\
\hline
\end{tabular}

Shown in Table (1): the relevant table to the sample homogeneity in the basic measurements that the torsion coefficients ranging between $(-0.49$ to 0.96$)$ which shows that the obtained measurements are close to the aggressive, where the torsion coefficient values ranging between $(+/ 3)$ as the splaying coefficient ranged between $(0: 12$ to 1.76) what means homogeneity research individuals. 


\section{Table (2): the numerical characterization of research sample according to the type of weapon}

\begin{tabular}{|l|l|l|l|l|l|l|}
\hline \multirow{2}{*}{$\begin{array}{l}\text { Weapo } \\
\text { type }\end{array}$} & \multicolumn{6}{|l|}{ Statistical indications } \\
\cline { 2 - 7 } & $\begin{array}{r}\mathrm{n} \\
\mathrm{n}\end{array}$ & $\begin{array}{l}\text { Pepetitionta } \\
\text { ge\% }\end{array}$ & $\begin{array}{l}\text { Chi- } \\
\text { square }\end{array}$ & $\begin{array}{l}\text { Freedo } \\
\mathrm{m} \\
\text { degrees }\end{array}$ & $\begin{array}{l}\text { Significan } \\
\text { ce } \\
\text { level }\end{array}$ & $\begin{array}{l}\text { indicatio } \\
\mathrm{n}\end{array}$ \\
\hline foil & 21 & 39.62 & 12.26 & 2 & 0.00 & $\begin{array}{l}\text { indicativ } \\
\text { e }\end{array}$ \\
\hline epee & 26 & 49.06 & & & & \\
\hline saber & 6 & 11.32 & & & & \\
\hline
\end{tabular}

It is seen from the table(2): the relevant to the numerical characterization of the research sample according to the type of weapon, that there were significant differences among the research sample individuals in the variable of weapon type (foil, epee, saber), where the value of Chi- square ranged 12.26 and that was the significant value at the level 0.05 .

\section{Tools used in the search}

1- Measuring the height to the most approximate centimeter by using the (rest miter).

2- Measuring the weight by using medical device.

3- Making questionnaire for exploring the experts' view about the injuries junior women duelist.

\section{Questionnaire application form}

The researchers succeeded through various studies to determine the questionnaire application form axes, which have been divided into five ones.

* The type of weapon and its relevance to the extent of being injured during practice fencing

*The type of weapon and its relevance to the type of injury *the type of weapon and its relevance to the injured part *the type of weapon and its relevance to the injury occurrence time 
*The type of weapon and its relevance to the reason of your exposure to injury (Annex 1)

The application form had been shown to the experts so the made some amendments (annex 2)

\section{Basic studies}

Basic studies had been conducted during the period from 14 / 6 / 2014 to the period $2 / 10 / 2014$, and this happened after the confirmation of the scientific coefficients of the form (Honesty stability) where the application form had been applied on the basic research sample, where numbered 53 duelist at different clubs including 21 players of foil, 6 of saber and 26 of epee duels.

\section{Statistical processors:}

Percentage - standard deviation -arithmetic means - honesty coefficient - simple correlation coefficient

\section{Presentation and discussion of the results:}

In light of research aims and questions, where the researchers conducted analytical study about the obtained data which was statistically processed by applying the proposed questionnaire about the type of used weapon in fencing and its relevance to the junior women duelist, and that was achieved by identifying the injury rate for each weapon and the rank of injuries that usually occur, and what are the most exposed body parts to injury and what is the most time of injury occurrence? And through the results we found the next:

Table (3): the type of weapon and its relevance to the extent of injury during fencing practice

\begin{tabular}{|l|l|l|l|l|}
\hline \multirow{2}{*}{$\begin{array}{l}\text { Weapon } \\
\text { type }\end{array}$} & \multirow{2}{*}{$\begin{array}{l}\text { Statistical } \\
\text { significance }\end{array}$} & \multicolumn{3}{|c|}{$\begin{array}{l}\text { Have you ever been injured during } \\
\text { fencing practice? }\end{array}$} \\
\cline { 3 - 5 } & & No & Somewhat & yes \\
\hline \multirow{2}{*}{ foil } & Number & 2 & 3 & 16 \\
\cline { 2 - 5 } & Percentage\% & 9.52 & 14.29 & 76.19 \\
\hline \multirow{2}{*}{ epee } & Number & 0 & 6 & 20 \\
\cline { 2 - 5 } & Percentage\% & 0.0 & 23.08 & 76.92 \\
\hline saber & Number & 0 & 0 & 6 \\
\hline
\end{tabular}




\begin{tabular}{|l|l|l|l|l|}
\hline \multirow{4}{*}{ Total } & Percentage\% & 0.00 & 0.00 & 100 \\
\cline { 2 - 5 } & Number & 2 & 9 & 42 \\
\cline { 2 - 5 } & Percentage\% & 3.77 & 16.98 & 79.25 \\
\hline
\end{tabular}

Table (3): the relevant to the extent of injury exposure during the fencing practice period shows:

*Foil weapon: was the highest repetition of the injury exposure during the period of weapon sports practice by $76.19 \%$ followed by (somewhat) by $14.29 \%$.

*epee weapon: was the highest repetition of the injury exposure during weapon sports practice by $76.92 \%$ followed by (somewhat) by $23.08 \%$.

*saber weapon: was the highest repetition of the injury exposure during the period of weapon sports practice by $100.00 \%$.

Total: was the highest repetition of the injury exposure during the period of weapon sports practice by $79.25 \%$ followed by (somewhat) by $16.98 \%$.

Table (3) shows that the totaling sample 53 of women duelist in the three weapons of fencing, that 51 players of them exposed to sports injuries, where was 19 women duelists of 21 injured in the foil weapon, and all sample individuals of the epee that was totaling 26 duelists were injured, as well as all players of the saber weapon were exposed to injury who were totaling six players, and this shows that $96.23 \%$ of the sample have been exposed to sports injuries in the three weapons, and researchers explained it that fencing is one of the games that contain many of the rapid movements in different directions to the body with counting of the arms and legs movements, leading to the occurrence of sports injury, in addition to table show that the women duelists attempt especially beginners to get into the high levels may be the cause of the exposure of more injuries. 
Anderson(1973) notes that injuries constitute a psychological\& physical barrier that represent an obstruction in the access to the high levels of the specialized sports, and lead to the duelist exclusion from fencing practice even if in partly way, which is reflected on his technical level. and sports activities despite its physical requirements, there is no doubt that it exposes a lot of practitioners to variant degrees of sports injuries, but that there is a relationship between the site of injury in the body, its type, its strength, and the type of practiced sport activity, in addition, the injury is not limited to only the periods of athletic competition, but also woman duelist may be exposed to it during the various stages of physical, skills, or planning preparation. (1:140)

Table (4) the weapon type and its relevance to the injury type

\begin{tabular}{|c|c|c|c|c|c|c|c|}
\hline \multirow{2}{*}{$\begin{array}{l}\text { Weapo } \\
\text { n type }\end{array}$} & \multirow{2}{*}{\begin{tabular}{|l|} 
Statistica \\
I \\
significa \\
nce
\end{tabular}} & \multicolumn{6}{|c|}{ Injury type } \\
\hline & & $\begin{array}{l}\text { Joints } \\
\text { sprain } \\
\text { s }\end{array}$ & $\begin{array}{l}\text { Spas } \\
\mathrm{m} \text { or } \\
\text { cramp } \\
\mathrm{s}\end{array}$ & $\begin{array}{l}\text { Joints } \\
\text { Disloca } \\
\text { tion }\end{array}$ & $\begin{array}{l}\text { The } \\
\text { muscles } \\
\text { or bones } \\
\text { ecchym } \\
\text { osis }\end{array}$ & $\begin{array}{l}\text { Bone } \\
\text { s } \\
\text { fract } \\
\text { ure }\end{array}$ & $\begin{array}{l}\text { Other } \\
\text { injuri } \\
\text { es }\end{array}$ \\
\hline \multirow[t]{2}{*}{ Foil } & Number & 1 & 14 & 1 & 4 & 0 & 1 \\
\hline & $\begin{array}{l}\text { Percenta } \\
\text { ge\% }\end{array}$ & 4.76 & 66.67 & 4.76 & 19.05 & 0.00 & 4.76 \\
\hline \multirow[t]{2}{*}{ Epee } & Number & 4 & 11 & 0 & 9 & 0 & 2 \\
\hline & $\begin{array}{l}\text { Percenta } \\
\text { ge\% }\end{array}$ & 15.38 & 42.31 & 0.00 & \begin{tabular}{|l|}
34.62 \\
\end{tabular} & 0.00 & 7.69 \\
\hline \multirow[t]{2}{*}{ Saber } & Number & 1 & 3 & 1 & 0 & 1 & 0 \\
\hline & $\begin{array}{l}\text { Percenta } \\
\text { ge\% }\end{array}$ & 16.67 & 50.00 & 16.67 & 0.00 & 16.67 & 0.00 \\
\hline \multirow[t]{2}{*}{ Total } & Number & 6 & 28 & 2 & 13 & 1 & 3 \\
\hline & Percenta & 11.32 & 52.83 & 3.77 & 24.53 & 1.89 & 5.66 \\
\hline
\end{tabular}


\begin{tabular}{|l|l|l|l|l|l|l|}
\hline & ge\% & & & & & \\
\hline
\end{tabular}

Shown from table (4) which is relevant to the type of weapon and injury type that:

Foil weapon: was the highest repetition of injury type in terms of spasms or cramps by $66.67 \%$ followed by muscles or bones ecchymosis by $19.05 \%$.

Epee weapon: was the highest repetition of injury type in terms of spasms or cramps by $42.31 \%$ followed by muscles or bones ecchymosis by $34.62 \%$.

Saber weapon: was the highest repetition of the injury type in terms of spasms or cramps by $50.00 \%$.

Total: was the highest repetition of injury type in terms of spasms or cramps by $52.83 \%$ followed by muscles or bones ecchymosis by $224.5 \%$

As shown from table (4), fencing injuries are not limited to one type or two types of injury but more ones that duelist get exposed to, also not restricted on type of weapons but there are three weapon types ( foil - epee - saber), but the rate of injury exposure differs where 28 women duelists exposed to spasms or cramps at reaching percentage $52.83 \%$ followed by muscles or bones ecchymosis by $24.53 \%$ while joints sprains reached $11.32 \%$, and the lowest percentage belonged to the bones fracture by $1.89 \%$, researchers demonstrate this to several reasons where the most important of it is skills variation that used by female duelists in fencing and the existence of specific area to it on the combat rug to use it, and the wrong practice plans for juniors to reach the high levels without planning, sufficient warming-up, insuring the proper nutrition, or return from injury before the entire healing.

Despite of the rare deadly injuries, but many studies had demonstrated to the effective injuries existence such as body wounds and holes. (2:16) (5:303) (6:265) (16:59),where sports injuries differ in terms of its nature, occurrence place, type, and its type according to the type of practiced activity, that every activity somewhat has its own danger classes what make it not clear of harms, especially trauma, dislocation, disruption, fractures and other harms what causing prevention and barring to the duelist for achieving his best 
performance because of lack of the physical efficiency what blocking the player from continuing and practicing maintenance. (17:19) (9:288)

Table (5) weapon type and its relevance to the injury occurrence in body parts

\begin{tabular}{|c|c|c|c|c|c|c|c|c|c|}
\hline \multirow{2}{*}{$\begin{array}{l}\text { Weapo } \\
\text { n type }\end{array}$} & \multirow{2}{*}{$\begin{array}{l}\text { Statistical } \\
\text { significan } \\
\text { ce }\end{array}$} & \multicolumn{8}{|c|}{ Body parts' injury occurrence } \\
\hline & & $\begin{array}{l}\text { Wris } \\
t \text { or } \\
\text { han } \\
\text { d }\end{array}$ & $\begin{array}{l}\text { Arm } \\
\text { (forear } \\
\text { m \& } \\
\text { upper } \\
\text { arm) }\end{array}$ & $\begin{array}{l}\text { Bac } \\
k\end{array}$ & $\begin{array}{l}\text { Abdome } \\
\mathrm{n}\end{array}$ & $\begin{array}{l}\text { thig } \\
\mathrm{h}\end{array}$ & $\begin{array}{l}\text { Kne } \\
\text { e }\end{array}$ & Leg & $\begin{array}{l}\text { Ankl } \\
\text { e }\end{array}$ \\
\hline \multirow[t]{2}{*}{ Foil } & No & 0 & 8 & 1 & 0 & 6 & 0 & 3 & 3 \\
\hline & $\%$ & 0.00 & 38.10 & 4.76 & 0.0 & $\begin{array}{l}28.5 \\
7\end{array}$ & 0.00 & $\begin{array}{l}14.2 \\
9\end{array}$ & $\begin{array}{l}14.2 \\
9\end{array}$ \\
\hline \multirow[t]{2}{*}{ Epee } & No & 4 & 6 & 0 & 1 & 3 & 3 & 4 & 5 \\
\hline & $\%$ & $\begin{array}{l}15.3 \\
8\end{array}$ & 23.08 & 0.00 & 3.85 & $\begin{array}{l}11.5 \\
4\end{array}$ & $\begin{array}{l}11.5 \\
4\end{array}$ & $\begin{array}{l}15.3 \\
8\end{array}$ & $\begin{array}{l}19.2 \\
3\end{array}$ \\
\hline \multirow[t]{2}{*}{ Saber } & No & 0 & 1 & 0 & 0 & 1 & 2 & 2 & 0 \\
\hline & $\%$ & 0.00 & 16.67 & 0.00 & 0.00 & $\begin{array}{l}16.6 \\
7\end{array}$ & $\begin{array}{l}33.3 \\
3\end{array}$ & $\begin{array}{l}33.3 \\
3\end{array}$ & 0.00 \\
\hline \multirow[t]{2}{*}{ Total } & No & 4 & 15 & 1 & 1 & 10 & 5 & 9 & 8 \\
\hline & $\%$ & 7.54 & 28.3 & 1.89 & 1.89 & $\begin{array}{l}18.8 \\
7\end{array}$ & 9.43 & $\begin{array}{l}16.9 \\
8\end{array}$ & $\begin{array}{l}15.0 \\
9\end{array}$ \\
\hline
\end{tabular}

As shown from table (5): which is relevant to weapon type and its relationship with injury occurrence parts we found:

Foil weapon: the most exposing part to injury occurrence was arm (forearm - upper arm) at ratio of $38.10 \%$ followed by thigh by $28.57 \%$ then leg and ankle by $14.29 \%$.

Epee weapon: the most exposing part to injury occurrence was arm (forearm - upper arm) at ratio of $23.08 \%$ followed by then leg and ankle by $19.23 \%$.

Saber weapon: the most exposing parts to injury occurrence were knee and leg at ratio of $33.33 \%$ to both of them followed by arm (forearm - upper arm) and thigh at ratio of $16.67 \%$ to both of them. 
Total: the most exposing part to injury occurrence was arm (forearm upper arm) at ratio of $28.30 \%$ followed by thigh at ratio of $18.87 \%$ then leg $16.98 \%$.

Table (5) shows that athletic injuries reached the whole body except head, and the most exposing part was arm (forearm - upper arm) at ratio of 8.30 followed by thigh a ratio of $18.87 \%$ then leg at ratio of $16.98 \%$.

This agrees with the view of (Ezequiel R.Rodriguez Rey) in the report of Olympic Games 2004 in Athena and Beijing 2008 where fencing participants at Athena reached 334 and 34 injuries had been recorded, while participants in Beijing reached 335 that included 25 recorded injury, and the most injuries were in the lower limb like ankle sprains, myorrhexis and ecchymosis followed by the upper limb injuries in wrest, arm and shoulders, and there was no life-threatening had been recorded. (4)

Each of (D.J Caine, P.A Harmer and M.A Schiff) had confirmed same above by identifying the most related injuries to fencing in Olympic Games, where more studies confirmed that the relative distribution of injuries for the anatomical location of body that most injuries were in the lower limb, especially in the ankle and knee. (3: 125)

Table (6) the weapon type and its relation to the injury occurrence timing

\begin{tabular}{|c|c|c|c|c|c|}
\hline \multirow{2}{*}{$\begin{array}{l}\text { Weapo } \\
\text { n type }\end{array}$} & \multirow{2}{*}{$\begin{array}{l}\text { Statistical } \\
\text { significan } \\
\text { ce }\end{array}$} & \multicolumn{4}{|c|}{ Injury occurrence timing } \\
\hline & & $\begin{array}{l}\text { The beginning } \\
\text { of the training } \\
\text { season period } \\
\text { (general } \\
\text { preparation) }\end{array}$ & $\begin{array}{l}\text { Mid- } \\
\text { season } \\
\text { training } \\
\text { (special } \\
\text { preparatio } \\
\text { n) }\end{array}$ & $\begin{array}{l}\text { During } \\
\text { compet } \\
\text { ition } \\
\text { periods }\end{array}$ & $\begin{array}{l}\text { During } \\
\text { the end of } \\
\text { the } \\
\text { training } \\
\text { season }\end{array}$ \\
\hline \multirow[t]{2}{*}{ Foil } & Number & 3 & 7 & 11 & 0 \\
\hline & $\begin{array}{l}\text { Percentag } \\
\mathrm{e} \%\end{array}$ & 14.29 & 33.33 & 52.38 & 0.0 \\
\hline \multirow[t]{2}{*}{ Epee } & Number & 6 & 7 & 11 & 2 \\
\hline & $\begin{array}{l}\text { Percentag } \\
\text { e\% }\end{array}$ & 23.08 & 26.92 & 42.31 & 7.69 \\
\hline
\end{tabular}




\begin{tabular}{|l|l|l|l|l|l|}
\hline Saber & Number & 2 & 2 & 2 & 0 \\
\cline { 2 - 6 } & $\begin{array}{l}\text { Percentag } \\
\text { e\% }\end{array}$ & 33.33 & 33.33 & 33.33 & 0.00 \\
\hline \multirow{3}{*}{ Total } & Number & 11 & 16 & 24 & 2 \\
\cline { 2 - 6 } & $\begin{array}{l}\text { Percentag } \\
\text { e\% }\end{array}$ & 20.75 & 30.19 & 45.28 & 3.77 \\
\hline
\end{tabular}

As shown from table (6) which is relevant to the weapon type and its relation to the injury occurrence timing that:

Foil weapon: the most timing of injuries occurrence during the competitions period reached $52.38 \%$ followed by the mid-season training (special preparation) at ratio of $33.33 \%$.

Epee weapon: the most timing of injuries occurrence during the competitions period reached $42.31 \%$ followed by the mid-season training (special preparation) at ratio of $26.92 \%$.

Saber weapon: the most timing of injury occurrence during the period of the beginning \& mid-season during competitions period reached $33.33 \%$.

Total: the most timing of injury occurrence during competitions reached $45.28 \%$ followed by the mid-season training (special preparation) at ratio of $30.19 \%$.

Table (6) shows that the athletic injuries that occurs to the female duelists during all periods of season whether it was at competitions period or the special and general preparation, the most timing of injury occurrence during the competitions period reached $45.28 \%$ followed by the mid-season training (special preparation) at ratio of $30.19 \%$.

Researchers explained so due to the competitive case among female duelists and attempting to reach the high levels and participation in championships even if they were not completely healed yet. 
Table (7) weapon type and its relation to the reason of your exposure to the injury

\begin{tabular}{|c|c|c|c|c|c|c|}
\hline \multirow{2}{*}{$\begin{array}{l}\text { Weap } \\
\text { on } \\
\text { type }\end{array}$} & \multirow{2}{*}{$\begin{array}{l}\text { Statistical } \\
\text { significan } \\
\text { ce }\end{array}$} & \multicolumn{4}{|c|}{ The reason of your injury exposure } & \multirow[b]{2}{*}{$\begin{array}{l}\text { Other } \\
\text { reaso } \\
\text { ns }\end{array}$} \\
\hline & & $\begin{array}{l}\text { Fitnes } \\
\text { s lack } \\
\text { and } \\
\text { dama } \\
\text { ge }\end{array}$ & $\begin{array}{l}\text { Performin } \\
\text { g wrong } \\
\text { movemen } \\
\text { ts during } \\
\text { training } \\
\text { and } \\
\text { competiti } \\
\text { on }\end{array}$ & $\begin{array}{l}\text { The lack } \\
\text { of warm- } \\
\text { up before } \\
\text { training } \\
\text { and } \\
\text { competiti } \\
\text { on }\end{array}$ & $\begin{array}{l}\text { The poor } \\
\text { condition } \\
\text { of the } \\
\text { tools, } \\
\text { equipmen } \\
t \text { and } \\
\text { playgroun } \\
\text { ds }\end{array}$ & \\
\hline \multirow[t]{2}{*}{ Foil } & Number & 1 & 11 & 2 & 1 & 6 \\
\hline & $\begin{array}{l}\text { Percentag } \\
\text { e\% }\end{array}$ & 4.76 & 52.38 & 9.52 & 4.76 & 28.57 \\
\hline \multirow[t]{2}{*}{ Epee } & Number & 0 & 13 & 6 & 1 & 6 \\
\hline & $\begin{array}{l}\text { Percentag } \\
\text { e\% }\end{array}$ & 0.00 & 50.00 & 23.08 & 3.85 & 23.08 \\
\hline \multirow[t]{2}{*}{ Saber } & Number & 0 & 4 & 2 & 0 & 0 \\
\hline & $\begin{array}{l}\text { Percentag } \\
\text { e\% }\end{array}$ & 0.00 & 66.67 & 33.33 & 0.00 & 0.00 \\
\hline \multirow[t]{2}{*}{ Total } & Number & 1 & 28 & 10 & 2 & 12 \\
\hline & $\begin{array}{l}\text { Percentag } \\
\text { e\% }\end{array}$ & 1.89 & 52.83 & 18.87 & 3.77 & 22.64 \\
\hline
\end{tabular}

Table (7) which is relevant to the weapon type and its relevance to the reason of your exposure to the injury shows that:

Foil weapon: the highest reasons of injury exposure were the performing of wrong movements during training or competition at ratio of $52.38 \%$ followed by other reasons at ratio of $28.57 \%$.

Epee weapon: the highest reasons of injury exposure were performing wrong movements during training or competition at ratio of $50.00 \%$ followed by the lack of warm-up before training or competition and other reasons at ratio of $23.08 \%$.

Saber weapon: the highest reasons of injury exposure were performing wrong movements during training or competition at ratio of 
$66.67 \%$ followed by lack of warm-up before training or competition at ratio of $33.33 \%$.

Total: the highest reason of injury exposure were performing wrong movements during training or competition at ratio of $52.83 \%$ followed by other reasons at ratio of $22.64 \%$ then the lack of warm-up before training or competition at ratio of $18.87 \%$.

Table (7) shows the plenty of sports injuries, where researcher found out several reasons that work on creating the injury such as: (bad condition of tools, equipments and playgrounds - lack of warm-up before training or competition - performing wrong movements during training or competition).

Hussein Haggag and Muhammad Samir Al-fekki (1988) mention that the possibility of injury occurrence in the athletic competition field is common, especially the characterized activity by friction with the opponent or the tool including combats in general and fencing in special, where the injury constitute a psychological and physical barrier that convert into an obstruction for reaching the high levels, also fencing expose it players to the occurrence of several and different injuries, and the possibilities of fencing injuries occurrence confirm the inevitability of creating the safety and security rules and not to involve the unprepared athlete in competition to protect him from the serious injuries while practicing the activity. (7:46)

Through the discussion of results we notice that the most of the three weapons (foil - epee - saber) duelists had been exposed to the injuries and not restricted to a weapon for another, that the most of injuries happened during competition, where the competition highlights among players in games, also not restricted to specific part from the anatomical locations of the player, but the most of injuries are exist in the lower limb and arms, and there are more reasons that lead to the duelist' injury including internal that belong to the player himself or external via training way or used devices, and other reasons.

So it's necessary to spread the rules of security and prevention in the different games to prevent the injuries occurrence and working on conducting more researches that discuss injuries prevention in all games, and modifying laws and devices of each game to assure the players' safety. 


\section{Findings:}

Based on study results could be reached to the next findings:

- Competition period in the season is the most periods that the female duelists expose to the injuries of the three weapons (foil - epee - saber).

- Reasons that lead to the injuries occurrence of the female duelists are varying, where the most important of it are the insufficient warm-up, the poor condition of tools, devices and playgrounds, and the lack and poor condition of fitness.

- The most exposed parts to the injuries are the lower limb, hand and wrest.

- Lack of awareness among players about the importance of commitment to the safety rules and injuries prevention.

\section{Recommendations:}

In the light of research connotations that concluded from the referred data and information in general, and from the responses of the sample individuals in special, researcher can form the next recommendations:

- Considering the provision of the safety and security factors of the used devices and playgrounds.

- Considering the warming-up before the players' training units and competitions.

- Considering the clubs and the weapon union by preparing medical records to the players determining the type and date of the player's injury and the return date from the injury whether for training or competitions.

- Not to allow the injured players to return to the playgrounds whether for training or competition without completing the healing process.

- Conducting more researches that considering the rules of safety and security to prevent games injuries in general and fencing in special way.

\section{References:}

1 Bob, Anderson $\quad$ Better Fencing Foil ,Kage Coward Ltd ,Fierst published By London.1973 


\begin{tabular}{|c|c|c|}
\hline 2 & $\begin{array}{l}\text { Carter, C., Heil, J. \& } \\
\text { Zemper, E }\end{array}$ & $\begin{array}{l}\text { What hurts and why-data from the } 1992 \text { USFA } \\
\text { Fencing Injury Survey shows some common } \\
\text { culprits. American Fencing (3), 16-17, 29. } 1993\end{array}$ \\
\hline 3 & $\begin{array}{l}\text { D.J. Caine, P.A. } \\
\text { Harmer and M.A. } \\
\text { Schiff }\end{array}$ & Epidemiology of Injury in Olympic Sports. 2010 \\
\hline 4 & $\begin{array}{l}\text { Ezequiel R. } \\
\text { Rodriguez Rey }\end{array}$ & $\begin{array}{l}\text { Acute Injuries in Olympic Fencing: Athens } 2004 \text { and } \\
\text { Beijing } 2008 \text { - NOVEMBER } 2008\end{array}$ \\
\hline 5 & Harmer, $\mathrm{P}$. & $\begin{array}{l}\text { Getting to the point: Injury patterns and medical } \\
\text { care in competitive fencing. Current Sports } \\
\text { Medicine Reports (5), 303-307.2008 }\end{array}$ \\
\hline 6 & $\begin{array}{l}\text { Harmer, P., Moriarity, } \\
\text { J., Walsh, M., Bean, } \\
\text { M. \& Cramer, J. }\end{array}$ & $\begin{array}{l}\text { Distant entry pneumothorax in a competitive fencer. } \\
\text { British Journal of Sports Medicine. 265-266. } 1996\end{array}$ \\
\hline 7 & $\begin{array}{l}\text { Hussein Ahmed } \\
\text { Assayed Haggag, } \\
\text { Mohamed Samir } \\
\text { Hassan Alfekki }\end{array}$ & $\begin{array}{l}\text { Study about common injuries in the sport of fencing, } \\
\text { the International Conference at the College of } \\
\text { Physical Education, Minia University, } 1988\end{array}$ \\
\hline 8 & $\begin{array}{l}\text { Hussein Ahmed } \\
\text { Assayed Haggag, } \\
\text { Ramzy Al tanbouli }\end{array}$ & $\begin{array}{l}\text { Foil fencing ( learning the essential skills - } \\
\text { Explanation of some methodologies of the law) } \\
\text { Alfath for printing and publishing, Alexandria, 2005 }\end{array}$ \\
\hline 9 & Kassem Khowaila & $\begin{array}{l}\text { Analytical Study for common injuries to athletes in } \\
\text { Jordan, unpublished master thesis, University of } \\
\text { Jordan, Amman, } 1997\end{array}$ \\
\hline 10 & $\begin{array}{l}\text { Mahassen Assayed } \\
\text { Muhammad, Effat } \\
\text { Hanem Muhammad }\end{array}$ & $\begin{array}{l}\text { The impact study of a proposed program for the } \\
\text { development of the reaction speed to the level of } \\
\text { performance of the offensive and defensive } \\
\text { movements in the subject of weapon for the } \\
\text { students of the Faculty of Physical Education } \\
\text { (Girls), Study and Research, Volume } 8 \text { issue2, } \\
\text { faculty of Physical Education for Girls, Helwan } \\
\text { University, } 1985\end{array}$ \\
\hline 11 & $\begin{array}{l}\text { Mohamed Khamis } \\
\text { Anwar }\end{array}$ & Sports injuries and first aids, 2015 \\
\hline 12 & Nick, $\mathrm{E}$ & The art and science of fencing. USA. 1996 \\
\hline 13 & $\begin{array}{l}\text { Osama abdul- } \\
\text { rahman Ali }\end{array}$ & $\begin{array}{l}\text { The impact of the training field variation on the } \\
\text { performance effectiveness of the under } 17 \text { y.o } \\
\text { juniors' legs movements, PhD thesis, unpublished, } \\
\text { faculty of physical education for men, Alexandria }\end{array}$ \\
\hline
\end{tabular}




\begin{tabular}{|l|l|l|}
\hline 14 & $\begin{array}{l}\text { University, } 1999 \\
\text { Roi, G. \& Bianchedi, } \\
\text { D. }\end{array}$ & $\begin{array}{l}\text { The science of fencing-implications for } \\
\text { performance and injury prevention. Sports Medicine } \\
\text { 465-481.2008 }\end{array}$ \\
\hline 15 & $\begin{array}{l}\text { Shaimaa Ahmed } \\
\text { Abdulkarim }\end{array}$ & $\begin{array}{l}\text { Faculty of physical education magazine, Baghdad } \\
\text { University, volume 22 Issue3, 2010 }\end{array}$ \\
\hline 16 & $\begin{array}{l}\text { Wild, A., Jaeger, M., } \\
\text { Poehl C., Werner, A., } \\
\text { Raab, P. \& Krauspe, } \\
\text { R. }\end{array}$ & $\begin{array}{l}\text { Morbidity profile of high-performance fencers. } \\
\text { Sportverletzung Sportschaden 59-61. 2001 }\end{array}$ \\
\hline 17 & $\begin{array}{l}\text { Zaynab Abdulhamid } \\
\text { Alalem }\end{array}$ & $\begin{array}{l}\text { Sports Massage and sport injuries,(Arabic thoughts) } \\
\text { house,1990 }\end{array}$ \\
\hline
\end{tabular}

